\title{
Conspiracy Theories and the Conventional Wisdom
}

\section{By}

\section{Charles Pigden}

\begin{abstract}
Conspiracy theories should be neither believed nor investigated - that is the conventional wisdom. I argue that it is sometimes permissible both to investigate and to believe. Hence this is a dispute in the ethics of belief. I defend epistemic 'oughts' which apply in the first instance to belief-forming strategies which are partly under our control. But the belief-forming strategy of not believing conspiracy theories would be a political disaster and the epistemic equivalent of self-mutilation. I discuss several variations of this strategy, interpreting 'conspiracy theory' in different ways but conclude that on all these readings, the conventional wisdom is deeply unwise.
\end{abstract}

\section{1) Political Ploys and Epistemic Principles}

The conventional wisdom on conspiracy theories is that they ought not to be believed. To call something 'a conspiracy theory' is to suggest that it is intellectually suspect; to call someone 'a conspiracy theorist' is to suggest that he is irrational, paranoid or perverse ${ }^{1}$. Often the suggestion seems to be that conspiracy theories are not just suspect, but utterly unbelievable, too silly to deserve the effort of a serious refutation. It is a common ploy on the part of politicians to dismiss critical allegations by describing them as conspiracy theories, a tactic of which Tony Blair was a master. The idea that the invasion of Iraq was 'all about oil' or that President Bush had considered bombing al-Jazeera were both 'conspiracy theories' and therefore not worth discussing ${ }^{2}$. This tactic would only be honest ${ }^{3}$ if Blair genuinely supposed that conspiracy theories as such ought not to be believed (except perhaps if

\footnotetext{
${ }^{1}$ For a detailed study of this polemical tactic see Husting, and Orr, (2007).

${ }^{2}$ See Coady (2006), p. 115 for details. Blair's comments on the bombing memo were particularly eloquent. "Look, there's a limit to what I can say - it's all sub judice, ... But honestly, I mean, conspiracy theories..." The Daily Telegraph, 28/11/2005. The matter was 'sub judice' because the Attorney General, presumably at Blair's behest, was prosecuting the people who had leaked the memo.

${ }^{3}$ I must admit to doubts about Blair's intellectual honesty. The second of these two allegations - that Bush seriously discussed the bombing of al-Jazeera, a suggestion that Blair apparently opposed - is born out by a leaked memo for which the leakers have been prosecuted. It may well be that Blair wanted to issue a non-denying denial; to dismiss the allegation without actually making the lying claim that the discussion had never taken place. Thus he claimed that the allegation was a conspiracy theory - which I suppose it is, though the conspiracy in question was not into put into effect - and should therefore be dismissed even though he was well aware that it was true. But in that case he cannot have consistently supposed that conspiracy theories as such are unbelievable, the kind of thing that rationally ought not to be believed, since the conspiracy theory he was talking about was not only true but provable on the basis of documentary evidence. Thus he may have avoided a direct lie but only by implying belief in an epistemic principle which he knew, or could have known, to be false.
} 
proven up to the hilt) and it would only be respectable if Blair's apparent belief were correct. Thus the tactic relies on the epistemic principle that in general, conspiracy theories ought not to be believed (that it is irrational to believe them), and indeed that they are mostly so irrational that they ought not to be discussed, except perhaps as symptoms of some ideological malaise.

Thus the conventional wisdom seems to be that we have an epistemic duty not to believe conspiracy theories, a duty which conspiracy theorists conspicuously neglect. I shall be denying that we have any such duty, and shall be arguing on the contrary that we are rationally entitled to believe in conspiracy theories, if that is what the evidence suggests. Some conspiracy theories are sensible and some are silly, but if they are silly this is not because they are conspiracy theories but because they suffer from some specific defect - for instance, that the conspiracies they postulate are impossible or far-fetched. But conspiracy theories as such are not epistemologically unclean, and it is often permissible - even obligatory - to believe them. For sometimes the case for conspiracy can be rationally overwhelming, 'proved beyond reasonable doubt', and even when it is not, belief in a conspiracy is often a rational option. Thus my dispute with the conventional wisdom is a debate about the ethics of belief. It is common ground in this debate that it makes sense to say that we ought to believe something (that believing it is right or rationally required), or that we ought not to believe it (that believing it is wrong, a sort of crime against reason). It also makes sense to say that we are entitled to believe something (since believing it is permissible). Furthermore, all these claims can aspire to truth though whether they actually are true is another matter. Thus Tony Blair's rhetoric carries some fairly heavy philosophical baggage. The point of dismissing the allegation that Bush considered bombing al-Jazeera as a 'conspiracy theory' was to suggest that we are under some sort of intellectual obligation not to believe it. But we can't be obliged not to believe conspiracy theories unless we have epistemic obligations.

But although the idea of epistemic duties may be common ground in the context of the current dispute, it is in fact a highly debatable. The difficulty derives from the Ought-Implies-Can principle (which presumably applies to the ethics of belief) combined with the idea that belief is not a voluntary business. The claim is that we cannot decide what to believe or disbelieve. When faced with certain 
considerations we are either moved by the evidence or we are not. Decision and choice do not enter into it. Even with practice we cannot decide, like the White Queen in Alice, ${ }^{4}$ to believe six impossible things - or six possible things - before breakfast. And it is equally impossible to decide not to believe six things before breakfast, whether the things in question are possible or not. But if Bloggs cannot help believing that agents of the Bush family detonated the Twin Towers, then it is not only pointless but actually false to say that he ought not to believe it. For you can't have an obligation to do what you cannot do and ex hyothesi, Bloggs in incapable of disbelieving that it was Bush family agents that did the deed. Thus the whole idea of an epistemic ethic is fundamentally cock-eyed, since it presupposes (wrongly) that we can control our beliefs.

This conclusion depends on two premises: Ought-Implies-Can and the idea that we cannot choose to believe. I am inclined to dispute them both. OughtImplies-Can is not a logical thesis but a plausible ethical principle that holds (with restrictions) in some systems of ethics but not in others ${ }^{5}$. It is not clear that it is has to be incorporated into a plausible ethics of belief. And though we cannot bring ourselves to believe just anything it seems to me that within limits we can often decide where to place our epistemic bets. The same thing goes for disbelief. Those who think otherwise sometimes counter by producing a random thesis and challenging you to believe it. When you can't, they claim victory, and if you insist that you can, their tendency is to scoff. But just because we cannot always chose to believe, it does not follow that we can never choose to believe, and where choice is a possibility, 'oughts' are not excluded. But though my first instinct is to challenge the premises, there is a better way of dealing with the claim that an epistemic ethic is a non-starter because we cannot choose to believe. For though we cannot always choose to believe we can often choose which belief-forming strategy to adopt. This is Pascal's response to the free-thinking gamblers who agree that it would be good idea to believe in God (since according to the Wager Argument, this would be the best bet), but who can't quite bring themselves to do so. Perhaps you cannot choose to

\footnotetext{
${ }^{4}$ Alice Through the Looking-Glass, ch. 5:
}

Alice laughed. 'There's no use trying,' she said: 'one can't believe impossible things.'

'I daresay you haven't had much practice,' said the Queen. 'When I was your age, I always did it for half-an-hour a day. Why, sometimes I've believed as many as six impossible things before breakfast. ${ }^{5}$ See Pigden, (1990). 
believe in God, he suggests, but you can choose to adopt a belief-forming strategy which is likely to bring about the desired result. If you go to church, hear masses and generally lead the life of a religious believer, the chances are that belief will follow - you will 'make yourself stupid' ${ }^{6}$. Other belief-forming strategies are less mind-numbing. For example, you can cultivate the habit of thinking up objections to claims that you would like to be true - a strategy that will make you less likely to confuse wishes with facts (a vice to which philosophers are peculiarly prone). Thus the best way to save an epistemic ethic is to take the deontic operators as applying, in the first instance, to belief-forming strategies rather than beliefs. What the conventional wisdom demands is not so much that we disbelieve this conspiracy theory or that, but that we adopt the intellectual habit of discounting, dismissing and disbelieving conspiracy theories (indeed of 'dissing' them generally). Rather than running around trying to evaluate the evidence, the sensible strategy is to shut our eyes to their intellectual charms. I advocate the alternative strategy of not dismissing conspiracy theories out of hand, simply because they are conspiracy theories, but of being prepared to investigate them and even to believe them if that is what the evidence indicates. Perhaps some conspiracy theories, are too way out to be worthy of investigation, but this is not because they are conspiracy theories but because the specific conspiracies that they postulate are absurd or improbable. For conspiracy theories as such are no less worthy of belief than theories of other kinds. Thus the dispute is primarily a debate about which belief-forming strategy to adopt rather than which claims to believe. Hence we can discuss the question sensibly as an issue in the ethics of belief even if we grant, what seems to me to be false, that we cannot choose to believe. For even if our beliefs are not directly under our control, our belief-forming strategies often are.

But what is the status of these epistemic 'oughts'? Are they categorical imperatives (Requirements of Reason) or hypothetical imperatives pointing out the means to achieve some widely shared but intellectually optional end, such as achieving an adequate understanding of the world? I incline to the latter view, though I suspect it would be a difficult business to specify the precise ends to which a respectable epistemic 'ought' prescribes the means. But whatever the precise status of epistemic 'oughts', the claim that we rationally ought to adopt a belief-forming strategy (such as not believing in or not enquiring into conspiracy theories), would

\footnotetext{
${ }^{6}$ Quoted and discussed in Mackie, J.L (1981) pp. 200-203.
} 
appear to presuppose that the strategy in question is conducive to truth and the avoidance of error, at least under a wide range of circumstances. Thus the rationale for the strategy of conspiratorial skepticism is that it is more likely to get it right or less likely to get it wrong than its epistemic rivals. It rests on the presumption that conspiracy theories are unlikely to be true, in fact so unlikely that they are generally not worth discussing. Indeed, it requires something stronger than the simple assumption that conspiracy theories, as such, are unlikely to be true. The space of possible theories is large; the space of true theories, small. But it would be silly to conclude from this that we ought to abstain from theorizing to avoid the risk of error. The fact that theories in general are more likely to be false than true does not mean that we should give up theorizing or enquiring into theories. By the same token, the fact that conspiracy theories are more likely to be false than true does not mean that we should give up conspiracy theorizing or enquiring into conspiracy theories. For that to be a sensible strategy we would have to suppose that conspiracy theories were much more likely to be false than their non-conspiratorial rivals. And since he seems to think that we ought not to believe or enquire into conspiracy theories, that is, presumably, the opinion of Tony Blair and the pundits of the conventional wisdom who apparently to agree with him.

\section{2) The Conventional Wisdom and Its Consequences: History is Bunk}

But if a conspiracy theory is simply a theory which posits a conspiracy - that is a secret plan on the part of some group to influence events by partly secret means and if a conspiracy theorist is someone who subscribes to a conspiracy theory, then the conventional wisdom itself is not just suspect, but obviously absurd. A theory, in my book, is a more or less organized body of propositions designed to explain some alleged facts. Theories can be true or false, well or badly confirmed, and when they are sufficiently well-confirmed, they can rise to the dignity of knowledge. Indeed in common parlance we can even talk about proving theories, though this is a usage that would shock true Popperians. Thus to call something a theory is not to suggest that it is tentative, speculative or unproven, though many theories are, of course, tentative, speculative or unproven. Now, if a conspiracy theory is simply a theory which posits a conspiracy, then every politically and historically literate person is a big-time conspiracy theorist, since every such person subscribes to a vast range of conspiracy theories. That is, historically literate people believe organized bodies of propositions that explain alleged facts by positing conspiracies. For there are many 
facts which admit of no non-conspiratorial explanation and many conspiracy theories that are sufficiently well-established to qualify as knowledge.

It is difficult, if not impossible, to mount a coup without conspiring, a point that is evident to all. Hence anyone who believes there are such things as coups must subscribe to a set of conspiracy theories however vague. Although some assassinations are due to 'lone gunmen' many are group efforts, and the efforts of those groups are usually planned in secret. (Had the plans of Brutus and Cassius been public, Caesar could have avoided the Senate House or arrested the potential murderers before they struck.) Thus anyone who knows anything about the Ides of March or the assassinations of Arch-Duke Franz Ferdinand or Tsar Alexander II is bound to subscribe to a conspiracy theory, and hence to be a conspiracy theorist. But coups and assassinations are not even the half of it. Disappearances are usually conspiratorial affairs, since if you want to disappear someone, you had better not let them know when you are coming. Of course, it can add to the fun if you let your victims know, in a general way, that somebody is out to get them (and many goons indulge this pleasure with threatening phone calls and other such 'warnings'), but if you are a member of a goon squad it is good idea to conceal your identity as well as your precise plans. And if you are organizing a campaign of disappearances, it as well to keep your activities secret. After all, picking up your political opponents and having them jailed, tortured or executed is generally regarded as not quite nice, particularly for Presidents and Prime Ministers. And you can never be quite sure that some tedious do-gooder from the International Criminal Court won't catch up with you in the end. Much the same considerations apply if you plan to clean up the city by butchering the local street kids. (Brazil, Columbia, Honduras.) Indeed, mass killings generally are often planned and partly executed in secret, the Holocaust being the supreme example, though one might also cite Stalin's purges. (It is strange to suppose the massacre of millions of people could be shrouded in secrecy but that is the way it was. Hannah Arendt, a Jewish activist with a passionate interest in politics, and as well informed as private person was likely to be, did not hear about 'Auschwitz' (by which, I presume she means the Nazi extermination program generally) until 1943, and did not regard it as a proven fact until six months later. ${ }^{7}$ ) If, like the 'Young Marshal', Zhang Xueliang, in $X^{\prime}$ ian $1937^{8}$, you plan to kidnap the

\footnotetext{
${ }^{7}$ See Arendt, Hannah 'What Remains? The Language Remains' in Baehr ed. (2000), p. 13.

${ }^{8}$ See Fenby (2003), pp. 1-18.
} 
Head of State with a view to coercing him into changing his policy, you had better not let him know in advance, and the operation had better be begun in secret to maximize the chance of success. Even at the everyday level of democratic politics, conspiracies are not uncommon. If my party leader is trailing in the polls and I am planning a leadership 'spill', I had best not let her know until I have a substantial number of MPs behind me. There is usually a good deal of secret plotting and furtive feeling out of potential supporters before a leadership challenge erupts into the open. In many countries it is not unknown for politicians and state officials to take bribes and misappropriate public funds. For obvious reasons, these activities are usually planned and executed in secret. Thus if you believe in such things you must be a conspiracy theorist of sorts, even if you are hazy about the details. Even in the small change of commercial life, conspiracies abound, a point acknowledged by Adam Smith, whose belief in he invisible hand of the market did not entail skepticism abut the invisible hands of individual conspirators: 'People of the same trade seldom meet together, even for merriment and diversion, but the conversation ends in a conspiracy against the publick, or in some contrivance to raise prices ${ }^{\prime 9}$. 'Masters too sometimes enter into particular combinations to sink the wages of labour even below this [actual] rate. These are always conducted with the utmost silence and secrecy, till the moment of execution'.$^{10}$ But I need not belabor a point that I have argued at length elsewhere ${ }^{11}$. History and the nightly news (not to mention common sense) all tell the same tale - people often conspire. Hence there is no reason to think that theories which postulate conspiracies are much more likely to be false than theories which explain the same events without the aid of conspiracies. Indeed there are many events for which there is no sane non-conspiratorial explanation. The Young Marshal's men did not individually decide without prior consultation to kidnap Chiang that day at X'ian in 1937, and if Mary Queen of Scots did not conspire to murder Lord Darnley at Kirk o' Fields in 1567, then somebody else did.

This suggests three conclusions:

\footnotetext{
${ }^{9}$ Smith (1981) An Inquiry into the Causes of the Wealth of Nations, vol. 1, p. 135.

${ }^{10}$ Smith (1981) An Inquiry into the Causes of the Wealth of Nations, vol. 1, p.84

${ }^{11}$ See Coady ed. (2006) pp. 17-18, 34-38, 157-60 \& 161-162.
} 
1) If conspiracy theories are theories which posit conspiracies, then the epistemic principle that, conspiracy theories as such ought not to be believed or even investigated is absurd. It only makes sense on the assumption that conspiracy theories are much more likely to be false than their non-conspiratorial rivals and this assumption is false. The ploy of dismissing critical allegations as conspiracy theories is not intellectually respectable, whatever the conventional wisdom may say.

If I manage to convince the learned and the semi-learned worlds of this (not just academics, but journalists and the punditocracy) I shall not have lived in vain. For the idea that conspiracy theories as such are intellectually suspect helps conspirators, quite literally, to get away with murder (of which killing people in an unjust war is an instance). If George Bush did seriously propose the bombing of al-Jazeera, then the President of the United States is the kind of man who is prepared to murder journalists for putting out news stories that he happens to dislike. And if there is evidence of this, which apparently there is, then it ought to be investigated. An epistemic principle that can help shield a politician from such an investigation is not merely ridiculous (though it is, of course ridiculous) - it's a threat to the common weal.

But important as this is, there are more interesting points to note. Brian Keeley (1999) contends that certain sorts of conspiracy theories ought not to be believed, not just because they are unlikely, but because to believe them would be to commit a sort of epistemic suicide. Following C.A.J. Coady, he argues that much of what we know, we know on the basis of testimony. If testimony is not largely reliable then we know virtually nothing. To suppose that testimony is largely unreliable is to suppose that we know virtually nothing, and this is something that we rationally ought not to believe. He then goes on to claim that many conspiracy theories - at least many that are castigated as such - require such a large amount of lying by so many people that they call testimony itself into question. To believe them is to suppose that testimony is largely unreliable and this is something that we ought not to believe. Therefore there are many conspiracy theories that we ought not to believe and the conventional wisdom is not so silly after all. 
This argument has two premises - a) the epistemic principle that we ought not to believe a thesis which requires such extensive lying as to call testimony into question, and b) the factual claim that many conspiracy theories require so much coordinated lying by so many people as to do precisely this. The first is dubious, the second false. But what I want to argue now is that the boot is on the other foot. There are better reasons of essentially the same kind for rejecting the epistemic principle that by and large we ought not believe or even investigate conspiracy theories.

2) History, as we know it, both from documentary evidence and the best historians, is choc-a-bloc with conspiracies. Thus if conspiracy theories are theories which posit conspiracies, then to accept the conventional wisdom and adopt the principle that we ought not believe or investigate conspiracy theories would lead to the conclusion that history is bunk, that much of what we thought we knew is not only unbelievable, but not worth investigating. Much of recorded history would dissolve into a blur of inexplicable events, indeed events we should not even try to explicate. To adopt this principle would be to commit historical suicide or at least self-mutilation, to make large chunks of history unbelievable and hence unknowable, since knowledge requires belief. It would maim, if not destroy, history as an intellectual discipline. But it is not rational to adopt an epistemic principle with such catastrophic consequences. Therefore it is not rational to suppose that we should not believe or even investigate conspiracy theories.

Perhaps it is worth stressing how catastrophic this principle would be, if consistently practiced. (In fact nobody does this - rather people like Blair apply it in a haphazard way when it happens to suit their political purposes.). We would be entitled to believe that large quantities of gunpowder were discovered in the cellars of parliament in 1605, but not that Guy Fawkes and his confederates put it there, for that would be a conspiracy theory. We could accept that Lord Darnley died, but not that anybody killed him, since all the available explanations are conspiracy theories. We could accept that the 'Rightist-Trotskyite Bloc' was put on trial in 1938, but we could not allow ourselves to believe that they were either guilty or innocent, since both beliefs entail a conspiracy. (If they were guilty then there was a treasonable 
conspiracy of spies and wreckers at the heart of the Soviet State. If they were innocent, there was a tyrannical conspiracy on the part of Stalin and others to fabricate the appearance of conspiracy.) We could notice that a lot of communists were massacred in China in 1927, but we could not rationally suppose that Chiang had conspired to kill them, for that would be a conspiracy theory. We could accept that World War II took place, but not that the Nazis conspired to wage it since that would be a conspiracy theory. (Good news for some of the Nuremburg defendants!) We could accept that the Holocaust occurred but not that anyone, Hitler included, conspired to bring it about. Moreover we would not even be allowed to investigate these questions, since any answer we came up with would be something we were not entitled to believe. If the conventional wisdom is correct, and we ought not to believe conspiracy theories, then history is bunk, since it is largely unbelievable, the kind of thing that we are rationally required not to believe. But history is not bunk much of it merits belief, and that includes the many conspiracy theories of which we have ample evidence. Thus the conventional wisdom is wrong and conspiracy theories need not be rejected simply because they are conspiracy theories ${ }^{12}$.

What about my third conclusion? This concerns political crimes and current events, the recent rather than the remote past.

3) Most political crimes - from disappearances and illegal bombing campaigns down to breaking peaceniks' noses or burglarizing the campaign headquarters of the opposition party ${ }^{13}$ - are the products of conspiracy. Thus if conspiracy theories are theories which posit conspiracies, then if we adopted the principle that we should not believe and should not investigate conspiracy theories, we could not hold anyone responsible for such crimes. For to do so would be to accept some conspiracy

\footnotetext{
${ }^{12}$ Here's an exercise for the reader. Get a second-hand copy of Fenby (2000) or Chang and Halliday, (2005).. Then cut out all the references to actions planned and partly executed in secret. My guess is that you would have, in effect, a much shorter book, and that the parts which remained would be disjointed and unintelligible. That would be the history of $20^{\text {th }}$ Century China without conspiracy. ${ }^{13}$ The Nixon administration was responsible for three of the above and probably connived at disappearances, at least in foreign parts (as Kissinger certainly did under Ford). But oddly enough, what brought the Nixon administration down was the Watergate Burglary and the ensuing cover-up, perhaps the least heinous of its many political crimes. For the illegal bombing campaign ('anything that flies, anything that moves'), see Shawcross (1986). For beating up peaceniks and burglarizing the opposition headquarters see Summers, (2000). On May $5^{\text {th }} 1971$, Nixon endorsed Haldeman's suggestion that they organize some 'thugs' from the Teamsters Union to 'beat the shit out of these people [the peaceniks] .. and smash some noses'. Abbie Hoffman's nose was duly smashed. See Summers (2000) pp. 356-357.
} 
theory or other. This would be an epistemic disaster, since our understanding of the political scene would dissolve in a mist of skepticism broken by islands of obvious fact. (We could believe in the dead bodies but not that anyone had conspired to kill them; believe in the missing money, but not in the felonious theft.). And it would a political disaster, since it would confer immunity on political criminals of all sorts, from the perpetrators of genocide down to bribe-taking congressmen. (We could not punish people for crimes that we were not entitled to believe in or investigate.) Thus it would be both politically and epistemically irrational to adopt the strategy of not believing in and not investigating conspiracy theories. So the conventional wisdom is wrong, and it is not the case that we ought not to believe and ought not to investigate such theories. When it comes to conspiracy theories we are within our rights as rational beings not only to investigate them, but actually to believe in them, if that is what the evidence suggests.

Again it is worth stressing just how catastrophic the strategy of conspiratorial skepticism would be if we applied it consistently (rather than using it from time to time to time to get out of political difficulties or to rubbish allegations that we find inconvenient). To begin with the political world would be largely unintelligible. We would be officially debarred from understanding coups, or the crimes of terrorists as intentional actions, since in both cases the intentions behind the overt acts are formulated in secret. Hence they cannot be understood as intentional acts without resorting to conspiracy. We could all acknowledge that the bombs had gone off but we could not suppose that someone had planted them, since that would be a conspiracy theory. We could accept that two planes had hit the Twin Towers but we could not allow ourselves to suppose they had been hijacked and deliberately crashed, since that could not have happened without a conspiracy. The nightly news would be bobbing with islands of unintelligibility, since we would be officially debarred from understanding any action involving secret plans. (I defy anyone to make sense of recent events in Iraq without taking account of the orgy of plotting that undoubtedly goes on. Death squads don't advertise their plans, neither do guerillas, gangsters, terrorists or devious politicians.) We would be allowed to understand natural phenomena and open actions, openly arrived at. And we might 
even treat ourselves to unintended consequences provided these did not involve secret plotting. But we would be officially blind to covert actions and secret plans. This would not quite be epistemic suicide, since there are some events within the political sphere that we would be allowed to understand. But to adopt the strategy of conspiratorial skepticism would be the epistemic equivalent of self-mutilation and hence not a rational thing to do.

But epistemically disastrous as conspiratorial skepticism would be, its political consequences would be catastrophic. For when it comes to conspiracy we would be both officially blind and officially incurious. Under this regime, Woodward and Bernstein would not have been allowed to investigate Watergate, and even if they had, nobody would have been rationally entitled to believe their results. Nixon would have gotten away with his crimes. For if conspiracy theories were taboo, there could be no question of impeaching the President for 'high crimes and misdemeanors', since most of those high crimes and misdemeanors were planned and executed in secret. The career of an investigative journalist like Seymour Hersh would stand condemned as one long exercise in irrationality since investigative journalism largely consists of investigating conspiracies and exposing them to the public gaze. If it is irrational to check out conspiracy theories, then the investigative part is a crime against reason, and if it is irrational to believe them, then the journalistic part is a crime against reason too, since it often consists in writing up conspiracy theories so as to encourage belief in the reader. One of the biggest problems with human rights abuses is impunity. Because the goons and their masters can usually get away with murder or (or worse ${ }^{14}$ ) they have no compelling reason to cease and desist. But since most human rights abuses are the products of conspiracy, if we adopted the strategy of neither investigating nor believing conspiracy theories, impunity would become rationally sacrosanct. We could not investigate human rights abuses since, for the most part, this involves investigating conspiracy theories, and even if we could, we could not condemn their perpetrators, since to do that we would have to accept a conspiracy theory. Conspiratorial skepticism would provide the torturers and killers with a charter of impunity since it would become an epistemic no-no to shine a light into the dark places where they

\footnotetext{
${ }^{14}$ For example disappearing pregnant women and allowing them to give birth in prison before murdering them (sometimes by tossing them out of planes over the Atlantic) and then adopting out their children to childless members of the Security Services - an Argentine specialty during the 'Dirty War' .
} 
commit their crimes. Terrorists too would be immune from investigation, let alone conviction, since their crimes are usually planned in secret. More generally, it is a platitude of liberal democracy that the price of liberty is eternal vigilance. At least part of what this means is that we must beware of power-hungry politicians conspiring to deprive us of our liberties. But if we were not allowed to investigate conspiracy theories then our vigilance would be confined to the public actions of politicians rather than their secret plans. We would have become officially blind to some of the most serious threats to liberty. And even if we somehow discovered such a conspiracy we would not be allowed to act on that discovery, since we could not act on a theory we had debarred ourselves from believing. According to Edmund Burke, 'There is no safety for honest men except by believing all possible evil of evil men.' But if the conventional wisdom is correct, we should not believe in the evil of evil men unless that evil were out in the open! Thus if you hate the freedoms of a democratic society, you should cultivate the opinion that conspiracy theories are unbelievable. Conversely, if you want to strike a blow for liberty (or if you want to be able to see the threats to liberty in order to be capable of striking a blow for it) this is a thesis you that should reject.

\section{3) What Then Does the Conspiracy-Skeptic Mean?}

If I am right, the conventional wisdom on conspiracy theories is not just misguided, but utterly absurd. For it implies an epistemic principle that flies in the face of history and would be politically catastrophic if put into practice. It would blind us to the machinations of torturers and scheming politicians, and would convert a large part of the political realm into a chaos of incoherent effects whose causes were beyond the reach of rational enquiry. But my conclusions only follow given an important proviso - that conspiracy theories are theories which posit conspiracies (which was why I was careful to put it into italics). But perhaps the pundits of the conventional wisdom mean something else by 'conspiracy theory' when they dismiss such theories as irrational. If he aspires to pragmatic consistency Tony Blair had better mean something else. For at the very period when he was dismissing conspiracy theories as not worth refuting, the foreign policy of the United Kingdom was officially based on not one but three distinct conspiracy theories (in the sense outlined) one true, and two false: 
1) That the events of $9 / 11$ were due to a conspiracy on the part of al-Qaeda (which was itself in league with the Taliban).

2) That the regime of Saddam Hussein was in cahoots with al-Quaeda, making him in some sense an accessory to the events of $9 / 11^{15}$.

3) That the regime of Saddam Hussein had successfully conspired to evade the UN inspectors and had acquired (or retained) weapons of mass destruction and was perhaps on the way (via the acquisition of yellowcake from Niger) to gaining a nuclear capability, thus making the regime a clear and present danger both to the UK and the US ${ }^{16}$

Thus it was presumably Blair's opinion that these conspiracy theories were not just permissible but rationally required. Blair's suggestion on the $18^{\text {th }}$ of March, 2003 that his 'honourable friend', the MP Lynne Richards should 'not be in any doubt at all' that 'Iraq ha[d] been supporting terrorist groups' ${ }^{17}$ suggests that she would have been making some kind of mistake had she thought otherwise. So what does he mean, and what do the pundits who agree with him mean, when they state or imply that conspiracy theories ought not to be believed? Not that theories that posit conspiracies ought not to be believed, since they themselves are prepared to posit theories of precisly this kind, for instance about the conspiratorial goings-on of alQaeda and other terrorist groups.

Perhaps Blair can be restored to consistency, if we reinterpret 'conspiracy theory' as a theory which posits a conspiracy, but also meets some other condition, $X$. One suggestion, current in the literature, is that a conspiracy theory is a theory which not only posits a conspiracy but also contradicts the official view, suggesting evil deeds by government officials or government agencies. The idea is that we are rationally

\footnotetext{
${ }^{15}$ The Prime Minister: [...] Secondly, to my hon. Friend, yes, I do support what the President said [that Iraq has aided, trained and harboured terrorists, including operatives of al-Qaeda]. Do not be in any doubt at all-Iraq has been supporting terrorist groups. Hansard 18/3/03.

${ }^{16}$ Prime Minister We are now just four days into this conflict. It is worth restating our central objectives. They are to remove Saddam Hussein from power, and to ensure that IRAQ is disarmed of all chemical, biological and nuclear weapons programs, but in achieving these objectives we have also embraced other considerations ... Hansard 24/3/05. This, of course presupposes that Saddam had weapons programs worth disarming and that they were sufficiently dangerous to make war a necessity.

${ }^{17}$ Hansard 18/3/03.
} 
required not to believe theories like that. It is all right to believe in conspiracies provided that they are consistent with received opinion, or provided that they don't involve wrong-doing by government officials. (Thus it was wrong to believe that the Gang of Four, were conspiring to persecute innocent Party members before they fell from power, but permissible to believe it afterwards, once the Party line had changed. Luckily for China, Deng Xiaoping and his confederates sinned against reason by believing in the conspiracy before it became the official view, and acted on that belief by taking steps to frustrate this unbelievable conspiracy!) Is this modified principle any better than its predecessor? Not much.

It is true that one of the conspiracy theories on which British foreign policy relied comes out as believable according to the revised principle. We can believe without irrationality that the events of 9/11 were due to a conspiracy on the part of al-Qaeda, since al-Qaeda is not a government agency, whilst the theory that alQaeda did it, is in fact, the received view. But what about the other two theories?

Here we hit a problem. The revised principle says that we should not believe conspiracy theories which contradict the official view and which posit evil deeds on the part of government personnel. But in Iraq the theory that Saddam was in cahoots with al-Qaeda was both inconsistent with the official view (which proclaimed that Saddam was innocent) and posited evil deeds on the part of the Head of State (since Saddam professed hostility to non-state terrorism). Thus in Iraq it was a conspiracy theory in the revised sense. Not so in Britain, because in Britain this theory was the official view and because the theory itself had nothing much to say about the actions of the British Government (of which Saddam was not a member). Thus it was permissible to believe the theory in Britain but rationally wrong to believe it in Iraq. The same goes for the third conspiracy theory on which Blair's policy rested - that Saddam had successfully conspired to acquire WMDs. In London it was believable but in Baghdad it was not. An epistemic principle which forbids a theory in Baghdad but allows it in London leaves something to be desired, but at least it saves Blair from the threat of pragmatic inconsistency, since as a London resident, he was rationally entitled to believe the theories on which his foreign policy depended.

Nevertheless the revised strategy would be an intellectual and political disaster if put into practice. Suppose we reinterpret 'conspiracy theory' along the 
lines suggested. The conventional wisdom metamorphoses into the claim that we should not believe or investigate conspiracy theories involving evil plots by government agents if this contradicts official opinion. But this can be given a relativistic or an absolute reading: either that you should not believe theories which depict evil conspiracies involving your own government which are inconsistent with the official view in your own country, or that that you should not believe theories which depict evil conspiracies involving any government and which are inconsistent with the official opinion anywhere.

On the relativistic reading, this principle permits some people to believe theories that it forbids to others, though those who are forbidden to believe may have better evidence for the theory than those who are allowed to accept it. For what it effectively means is that you are not allowed to believe in evil conspiracies perpetrated by associates of your own government but only in evil conspiracies perpetrated by other governments elsewhere. We must be local skeptics even though we are allowed to be international believers. If people all around you are being disappeared by Death Squads and you are tempted (despite the President's denials) to suspect government complicity, the revised epistemic principle insists that you resist this temptation, even though people on the other side of the world, who don't have access to your evidence, are quite at liberty to believe it! The strategy might not be historically disastrous, since you would be allowed to believe in conspiracy theories about the dark doings of previous governments, so long as they were consistent with the official view. But in many countries it would render current events unintelligible, since in many countries evil conspiracies on the part of government members dominate the political scene. (This is par for the course in authoritarian and totalitarian societies and is not unknown even in countries which approximate democracy.) And in rendering the populace politically blind the strategy would render them politically impotent. You can't even begin to solve a problem if you have shut your eyes to its existence.

The absolute version of this strategy would be slightly less bizarre but even more catastrophic. It would be less bizarre since what is rational to believe would not vary from place to place. But it would be more catastrophic since it would debar us from believing in evil conspiracies on the part of governments anywhere if those theories were inconsistent with some official view. Bad news for Amnesty 
International, bad news for their clients the world over as they are imprisoned, beaten, murdered and tortured, since you can't write letters on behalf of people whose problems you are not allowed to believe in.

But I need not spill any more ink denouncing a strategy that nobody seriously advocates. For the concept of a conspiracy theory as it is commonly employed is clearly a chauvinist construct. It is not to be understood in terms of governments generally, but in terms of Western governments, and recent Western governments at that. When people say or imply that conspiracy theories ought not to be believed, they don't just mean that we should not believe theories that postulate conspiracies. Nor do they mean that we should not believe theories which run counter to some official view and which posit evil schemes on the part of some government or other. For they themselves are often eager to trumpet such theories. (Witness Blair and Bush, both officially conspiracy-skeptics, who based, or claimed to base, their foreign policies on the three conspiracy theories listed above.) What they actually mean (in so far as they have a coherent idea) is that we should not believe theories which postulate evil schemes on the part of recent or contemporary Western governments (or government agencies) and which run counter to the current orthodoxy in the relevant Western countries. (This still allows a distressing degree of relativism. In Europe you can believe that American agents kidnap terrorism suspects with a view to having them tortured in foreign parts, since that is consistent with received opinion, but in America you ought not, since the 'torture' bit of this story is officially played down or denied.) Thus you can believe that Saddam had successfully conspired to acquire nuclear weapons since the chief conspirator in this particular drama was not a member of a Western government. And you can believe that members of the Reagan administration conspired to evade the Boland Amendment by selling arms to Iran to finance the Contras, since the existence of this conspiracy is currently consistent with official opinion. But you must not believe that Bush considered bombing al-Jazeera (let alone that the earlier bombings of alJazeera offices were intentional) for that theory involves evil schemes on the part of a Western leader and contradicts the official view, which is that this allegation is 'outlandish'. (BBC News 22/11/05) Thus we can restore Bush and Blair to pragmatic consistency (along with their allies in the punditocracy) by giving a chauvinistic reading to the concept of a conspiracy theory. In effect, the strategy they suggest is that of not believing and not investigating theories which posit evil schemes on the 
part of Western governments or Western government agents and which contradict official opinion as it is currently understood. Their conspiracy theories are not like this.

Is this a sensible belief-forming strategy? Obviously not. An epistemic strategy should maximize the chances of truth and minimize the chances of error. But if this strategy had been pursued in the past, many politically important truths would never have come to light. A hypothesis counts as a conspiracy theory in this sense if it postulates evil schemes on the part of government members and is inconsistent with the official view (where the governments in question are Western governments). Thus there are many theories which are not conspiracy theories now, though they were conspiracy theories in the past: the theory that the Kennedy administration conspired to overthrow Diem; the theory that CREEP conspired to burglarize the Democratic headquarters in the Watergate building and that Nixon conspired to cover it up; the theory that Nixon conspired with the Mob to have peaceniks beaten up; the theory that Nixon and Kissinger conspired to overthrow Allende and connived at the subsequent murders and brutalities; the theory that members of the Reagan administration conspired to sell weapons to Iran in order to fund the Contras; and the theory that suspected terrorists are being kidnapped and tortured at the behest of the Bush administration ${ }^{18}$ - all these theories were once inconsistent with official opinion, though nowadays official opinion has managed to catch up with the facts (except perhaps in America where official opinion is still a bit iffy about 'extraordinary rendition'). Thus it would have been an epistemic mistake to have adopted this strategy in the past. More importantly, it would have been a political mistake. If these activities had gone unnoticed, there would have been no check on the abuse of Presidential power, which would probably have gone on to worse excesses. The price of liberty is eternal vigilance. The revised strategy would have sent us to sleep.

Thus the conventional wisdom has proved to be unwise. On any of the readings of 'conspiracy theory' that I have been able to come up with, it is not the case that we should neither believe nor investigate conspiracy theories. If you wish

\footnotetext{
${ }^{18}$ I trust nobody objects to this litany of American examples. It is just that I am well acquainted with recent American history (which is of peculiar importance to the world) but am less so with that of other countries. I'm sure that similarly discreditable tales could be told about other Western democracies.
} 
to vindicate the conventional wisdom, you must do two things. First you must give an interpretation of the term 'conspiracy theory' with roughly the right extension. (Most of the theories castigated as 'conspiracy theories' must qualify as such, and most of the conspiracy-postulating theories that conspiracy skeptics believe in must not.) You must then show that on this interpretation, the strategy of neither investigating nor believing conspiracy makes epistemic sense. Until this is done, the idea that conspiracy theories as such are intellectually suspect is a superstition that can be safely dismissed.

\section{References}

Baehr, Peter ed. 2000. The Portable Hannah Arendt, Harmondsworth, Penguin.

BBC News, Tuesday, 22 November 2005,

http: / / news.bbc.co.uk/2/hi/uk_news/politics/4459296.stm

Carrol, Lewis. 1871. Through the Looking-Glass, and What Alice Found There, Adelaide etext version, http: / / etext.library.adelaide.edu.au/c/carroll_l/looking / looking, html

Chang, Jung and Halliday, Jon. 2005. Mao: the Unknown Story, London, Jonathan Cape

Coady, David ed. 2006. Conspiracy Theories: the Philosophical Debate, London, Ashgate.

Fenby, Jonathan. 2003. Generalissimo; Chiang Kai-Shek and the China he Lost, London, Free Press

Husting, Ginna and Orr, Martin. 2007. 'Dangerous Machinery: "Conspiracy Theorist" as a Transpersonal Strategy of Exclusion', Symbolic Interaction, Vol. 30, No. 2, Pages 127-150.

Keeley Brian L. 1999. 'Of Conspiracy Theories' The Journal of Philosophy, 96 (3): 109-126, reprinted in Coady ed. (2006) pp. 45-60

Mackie, J.L. 1981. The Miracle of Theism, Oxford, Oxford University Press, pp. 200-203.

Pigden, Charles. 1990. 'Ought-Implies-Can: Luther, Erasmus and R.M. Hare', Sophia, vol 29 , no.1 pp. 2-30

Shawcross, William. 1986. Sideshow: Kissinger, Nixon and the Destruction of Cambodia, London, Hogarth Press.

Summers, Anthony. 2000. The Arrogance of Power: the Secret World of Richard Nixon, London, Gollancz.

Smith, Adam. 1981. An Inquiry into the Causes of the Wealth of Nations, vol. 1, edited by Campbell, Skinner and Todd, Indianapolis, Liberty Fund.

\section{Academic Biography}

Charles Pigden teaches philosophy at the University of Otago, New Zealand and is the editor of Russell on Ethics. He has published on abstract objects, the analytic/synthetic distinction, negative facts, conspiracy theories, the Milgram experiments and the Is/Ought Problem, as well as articles on Moore, Geach, Russell, Hume Nietzsche, Mackie, Anscombe, and Dostoevsky. If pressed, he will admit to being a meta-ethicist. 